УДК 32:322(477)

https://doi.org/10.34142/24130060.2019.19.2.04

\title{
ВПЛИВ РЕЛІГІЙНИХ ОРГАНІЗАЦІЙ НА ДЕРЖАВОТВОРЕННЯ В УМОВАХ СУЧАСНИХ СУСПІЛЬНИХ ЗМІН В УКРАЇНІ
}

\author{
П.І. Коновальчук \\ Національний інститут стратегічних досліджень
}

У статті обтрунтовано особливості та доцільність впливу релігійних організацій на процеси державотворення в умовах сучасних суспільно-політичних змін в Україні. Проаналізовано історично-суспільну сутність релігії. Виділено основні положення щзодо суспільно-політичної спрямованості діяльності иеркви в соиіально-історичному контексті та в сучасних умовах. Розглянуто етапи становлення иеркви як соціального інституту в демократичному суспільстві, відмінності між суб'єктивною (ставлення до Бога) та об'єктивною (історична реальність) релігіями. Розкрито підходи до аналізу питань взаємозалежності релігії та політики. Уточнено можливі варіанти взаємовідносин влади та иеркви в контексті різних політичних устроїв. Наголошено на значимості та авторитетності иеркви в пошуку взаємоприйнятих рішень у багатьох проблемних ситуачіях в умовах гібридної війни.

Конкретизовано поняття «легітимність» як важливу ознаку демократичної влади, символ довіри, уявлення, щзо існують у свідомості громадян та трунтуються на законності влади, визнанні громадянами прав та обов'язків як ї̈ керівників, так $i$ своїх. Проаналізовано типи легітимності державної влади. Виділено чинники впливу релігійних організацій на державотворення в Украйні. Розглянуто функції иеркви як соціального інституту в демократичному суспільстві. Окреслено основні напрями оптимізації впливу релігійних організацій на державотворення: утвердження позииій Автокефальної Української Помісної Церкви; подолання міжконфесійних конфліктів; подальше позитивне вирімення украӥнського релігійного питання на міжнародному рівні; законодавчого уточнення статусу иеркви в суспільно-політичних процесах; формування політично-релігійної складової суспільства. Підтверджено ефективність взаємодї релігійних та державних інституиій у розбудові краӥни, прийняття важливих політичних рішень на спільній основі.

Ключові слова: державотворення, релігійні організації, держава, легітимність, церква, політика, гібридна війна.

\section{ВЛИЯНИЕ РЕЛИГИОЗНЫХ ОРГАНИЗАЦИЙ НА ПОСТРОЕНИЕ ГОСУДАРСТВА В УСЛОВИЯХ СОВРЕМЕННЫХ ОБЩЕСТВЕННЫХ ИЗМЕНЕНИЙ В УКРАИНЕ}

\section{П.И. Коновальчук}

В статье обосновань особенности и целесообразность влияния религиозных организаций на прочессы построения государства в условиях современных общественнополитических изменений в Украине. Проанализирована историко-общественная сущность религии. Выделены основные положения по общественно-политической направленности деятельности церкви в сочиально-историческом контексте и в современных условиях. Рассмотрень этапь становления церкви как сочииального

(C) П.І. Коновальчук, 2019 
института в демократическом обществе, различия между субъективной (отношение к Богу) и объективной (историческая реальность) религиями. Раскрыто подходы к анализу вопросов взаимозависимости религии и политики. Уточнены возможные варианты взаимоотношения власти и церкви в контексте различных политических строев. Отмечено значимость и авторитетность церкви в поиске взаимоприемлемых решений во многих проблемных ситуачиях в условиях гибридной войны.

Конкретизировано понятие «легитимность» как важный признак демократической власти, символ доверия, представления которые, существуют в сознании граждан и основьваются на законности власти, признании гражданами прав и обязанностей как ее руководителей, так и своих. Проанализировань типь легитимности государственной власти. Выделены факторы влияния религиозных организаций на построение государства в Украине. Рассмотрень функции ичеркви как социиального института в демократическом обществе. Определены основные направления оптимизации влияния религиозных организаџий на государство: утверждение позиций Автокефальной Украинской Поместной Церкви; преодоление межконфессиональньх конфликтов; дальнейшее положстельное решение украинского религиозного вопроса на международном уровне; законодательного уточнения статуса церкви в общественнополитических процессах; формирование политико-религиозной составляющей общества. Подтверждена эфффективность взаимодействия религиозных и государственных институтов в развитии страны, принятию важных политических решений на совместной основе.

Ключевые слова: построение государства, религиозные организации, государство, легитимность, церковь, политика, гибридная война.

\section{THE INFLUENCE OF RELIGIOUS ORGANIZATIONS ON STATE- BUILDING IN THE CONDITIONS OF MODERN SOCIAL CHANGE IN UKRAINE}

\section{P. Konovalchuk}

The article substantiates the peculiarities and expediency of influence of religious organizations on the processes of state formation in the conditions of contemporary sociopolitical changes in Ukraine. The historical and social nature of religion is analyzed. The main provisions on the socio-political orientation of the church's activity in the socio-historical context and in the present conditions are highlighted. The stages of becoming a church as a social institution in a democratic society, the distinction between subjective (attitude to God) and objective (historical reality) religions are considered. Approaches to the analysis of issues of interdependence of religion and politics are revealed. Possible variants of the relationship between the authorities and the church in the context of different political structures have been clarified. The importance and authority of the church in finding mutually acceptable solutions in many problematic situations in a hybrid war is emphasized.

The concept of «legitimacy» is specified as an important sign of democratic power, a symbol of trust, beliefs that exist in the minds of citizens and are based on the legitimacy of the authorities, citizens' recognition of the rights and duties of both their leaders and their own. The types of legitimacy of state power are analyzed. The factors of influence of religious organizations on state formation in Ukraine are highlighted. The functions of the church as a social institution in a democratic society are considered. The main directions of optimization of influence of religious organizations on state formation are outlined: approval of the positions of the Autocephalous Ukrainian Local Church; overcoming interfaith conflicts; further positive resolution of the Ukrainian religious issue at the international level; legislative clarification of the status of the church in socio-political processes; formation of political and religious 
component of society. Effectiveness of interaction between religious and state institutions in the country's development, making important political decisions on a common basis were confirmed. hybrid war.

Key words: state formation, religious organizations, state, legitimacy, church, politics,

Постановка проблеми. Історичний хід подій в європейських країнах свідчить про значущість влади та церкви в процесах державотворення. У період XVII - XVIII ст. влада хоча й відігравала основну роль у державі, але при цьому керувалася підтримкою релігійних організацій, котрі були причетними до іiі створення. Взаємозв'язок політики та релігії тісно простежувався у системі суспільних і правових взаємовідносин. Згодом, набула поширення ідея незалежності релігійного та суспільного життя, яка стала головною ознакою політичного устрою багатьох держав. Різні держави світу 3 отриманням статусу самостійності поступово почали відокремлюватися від церкви, яка стала окремим соціальним інститутом формування системи духовних цінностей у суспільстві. Однак, навіть у XXI столітті питання щодо розділення функцій політики та релігії в процесах державотворення $\epsilon$ дещо суперечливими та потребують ретельного наукового аналізу. Всупереч заявам деяких політичних діячів, що релігія не має ніякого відношення до державних питань, іiі вплив особливо чітко проявляється в сучасній політиці, зокрема, в умовах гібридної війни. Саме під час такої непроголошеної війни спільна мета держави та релігійних інститутів виділяється із загальних напрямів європейського розвитку та стає провідною у дискусіях щодо нового політично-релігійного контексту. Тому в умовах сучасних суспільно-політичних змін в Україні роль релігійних організацій у процесах державотворення $\epsilon$ неоднозначною, що актуалізує необхідність певного наукового дискурсу.

Аналіз актуальних досліджень. Питання церковно-політичного характеру історичного становлення держав були предметом наукових досліджень багатьох учених. Так, французький філософ А. Мішель приділяв увагу аналізу взаємовідносин церкви та держави в епохи адміністративної монархії XVII ст. та освіченого деспотизму XVIII ст. Загальні проблеми 
взаємодії релігійних та світських інституцій були висвітлені на сторінках праць І. Лортца, А. Павлова, Н. Суворова та ін. Ракурс розгляду питання пріоритетів релігії та влади в житті держави змінювався протягом багатьох років. Найбільш переломним періодом у дослідженні взаємовідносин релігії та політики стали 40-80-ті роки XX ст., коли державу і релігію дослідники не ототожнювали та вважали антиподами одна одній. Значні зміни в підходах до вирішення окресленої проблематики розпочалися 3 90-х років ХХ ст. Відбувається поступовий відхід від схематичних побудов попереднього періоду, заглиблення у проблему стає значущим, проблеми церковнодержавних взаємовідносин набувають актуальності та нового трактування.

Сучасні науковці акцентують увагу на тих релігійних питаннях, які мають політичне спрямування та суттєво впливають на розвиток української державності (М. Бабій, В. Бондаренко, В. Горбулін, А. Киридон, О. Кисельов, В. Климов, І. Онищук, С. Сьомін, П. Яроцький). Зокрема досліджуються: теорії релігійного бачення світу через призму суспільної свідомості (Т. Євдокимова, М. Закович), функції церкви в сучасному суспільстві (B. Єленський, I. Коваль, А. Колодний), релігійні чинники та засоби гібридної війни (С. Здіорук, М. Розмуний, О. Саган, Є. Сверстюк, М. Степико, В. Яблонський).

Огляд наукових робіт з проблем взаємовідносин держави та церкви дозволяє зробити висновок про необхідність розгляду зазначеного питання в розрізі впливу релігійних організацій на державотворення в умовах сучасних суспільно-політичних змін в Україні. Актуальними є завдання аналізу питань взаємозалежності релігії та політики в контексті визнання легітимності державної влади, пошуку взаємоприйнятих рішень у проблемних політичних ситуаціях, функцій церкви як соціального інституту підтримки демократії.

Мета статі полягає в аналізі особливостей впливу релігійних організацій на державотворення в умовах сучасних суспільних змін в Україні. 
Виклад основного матеріалу. Україна на арені сучасних політичних та соціально-економічних зрушень демонструє значущість церкви, яка стала значущим чинником у зміцненні та розбудові нашої держави. Сучасна українська церква, як органічна складова суспільно-політичних процесів, потужно заявила про себе в період гібридної війни та утвердила своє місце в політичній системі держави. Духовні цінності, моральні переконання та підтримка, якими керується православна, та інші загальновизнані в Україні релігії, мають авторитетне значення в українському суспільстві. Оскільки релігійні організації здійснюють вагомий вплив на світосприйняття як своїх прихожан, так й інших людей, то вони є значним фактором впливу на український електорат. Тому, як зазначає Т. Свдокимова (2002, с. 16), релігійні питання стали актуальними для української державності. Водночас існують певні проблеми у взаємовідносинах політики та релігії у соціокультурному просторі, адже ця взаємодія може вести до конфронтації та напруженості в суспільному середовищі. Окрім того, співпраця політичних та релігійних організацій є значущою в умовах розбудови державності та піi національно-духовного відродження. Їх взаємодія $\epsilon$ атрибутом демократичності та ознакою громадського суспільства.

Варто наголосити, що відповідно до законодавства України, церква від початку незалежності $є$ відокремленою від держави, що, у свою чергу, передбачає й відокремленість від політичного життя. У документі «Рекомендація №1396 з релігії та демократії» (Парламентська Асамблея Ради Європи, 1999) також йдеться про основні вимоги до інститутів релігії та політики. Зокрема в ньому вказано, що політика ніяким чином не повинна втручатися у вирішення релігійних питань, у свою чергу, релігія не має займати місце демократії. Такі рекомендації є зрозумілими та потребували б дотримання. Однак, враховуючи стан гібридної війни, в якому перебуває українське суспільство, релігійні організації активно включаються в політичні процеси. На думку багатьох політиків та науковців саме релігійні інституції є найбільш дієвими у вирішенні низки конфліктних ситуацій, що 
пов'язані з воєнними діями на Сході України. Рівень довіри громадян у період гібридної війни до церкви значно виріс у порівняні з політичними представниками влади. Тому iї авторитет може стати запорукою пошуку взаємоприйнятих рішень у багатьох проблемних ситуаціях.

Щоб аналізувати питання релігійного характеру в українському соціумі, варто звернути увагу й на історично-суспільну сутність релігії. Ми не аналізуємо релігійні концепції з точки зору релігієзнавства, а розглядаємо основні релігійні чинники, які безпосередньо впливають на сучасне суспільство в умовах суспільно-політичних змін, зокрема $\mathrm{i}$ на його державотворення. Гібридна війна, як один 3 інструментів цього впливу, потужно використовує інформаційні ресурси релігійних організацій.

Німецький дослідник Е. Трельч (Гараджа ред., 1996) обгрунтовує думку, що релігія водночас суб'єктивна та об’єктивна реальність. 3 його точки зору, суб'єктивна реальність - це свого роду, ставлення до Бога, що стосується об'єктивної - вона вибудовується на історичній реальності. В такому контексті почали будуватися відносин суспільства й релігії. Релігієзнавці стверджують, що соціум, у широкому розумінні суспільство, та релігія відокремленні одна від одної та існують як «самостійні величини». Соціальними аспектами наділені лише явища релігії, а також релігійні організації, установи. Філософи вказують на те, що релігійні ідеї та принципи неухильно опановують світську сферу, яка вже не є позарелігійною. У свою чергу, дослідник Д. Філпот $(2007$, с. 505) наголошує, що релігія є політично неоднозначною, iї практикують і вимірюють багатьма різними способами, а саме, кожна релігія несе свою місію і трактує слово Боже виключно зі своїх віросповідань. Така розбіжність $є$ результатом різних політичних наслідків, які не варто поєднувати. Різноманітність цього досвіду робить узагальнення щодо релігії та політики надзвичайно складними, особливо в порівняльній перспективі. У Православ'ї зв'язок між релігією та будь-якою політичною діяльністю здійснюється через різноманітність релігійних традицій, вірувань та обрядів. 
Водночас, релігія, в іï різних формах, може слугувати популяризації режимів практично будь-якого типу політичного устрою, демократичного або іншого, й може так само легко ослабити чи й зовсім знищити моральні основи цих режимів. Релігія, яка охоплює майже нескінченну різноманітність переконань, поведінки та дійових осіб, впливає на свій політичний контекст багатоманітним набором засобів. Для влади це різноманіття може бути корисним або небезпечним. Релігія не є по суті революційною, але вона і не $\epsilon$ про-антидемократичною. Більшим чином вплив релігї проявляється в тому, як вона взаємодіє 3 політикою, яку роль вона відіграє у підтримці або запереченні легітимності держави, ii керівництва, ідеології тощо.

У певних умовах релігія була основою недемократичного правління. В інших ситуаціях вона виступала каталізатором для зняття диктаторів на користь демократичних альтернатив. Теологічні відмінності можуть лише частково пояснити ці варіанти. Одна й та сама релігійна традиція може слугувати захистом авторитаризму в одному випадку, але прибічником демократії в іншому. В поясненні цих відмінностей ключове значення належить політичним аргументам. Аналізуючи такий досвід варто звернути увагу на діяльність релігійних спільнот, котрі за різних обставин по різному вели свою політику. Будучи усуненими чи маючи утиски зі сторони держави, вони виступали за рівність релігії та співпрацю 3 іiі послідовниками. У випадку домінантності, релігія завжди зверталася до політичної влади для зміцнення свого впливу серед суспільно-політичного життя. При таких обставинах політика йшла назустріч релігії, тим самим використовувала іiі потужний мобілізаційний потенціал у власних цілях. Як наслідок можна отримати релігієзацію політики, чи навпаки, політизацію релігії (Розенфельд та ін., 2001, с. 116).

Важливу роль релігія відіграє при підтримці демократії та протидії диктатури. За таких обставин формується їі ставлення до наявних та потенційних політичних інститутів. Політична влада отримає підтримку від громадян в тому випадку, коли вона сформована демократичним шляхом, 
окрім того має підтримку в суспільному просторі, визнається ним та іншими державами. Така влада має значущу перевагу серед населення, адже вона може встановити оптимальні політичні відносини між усіма верствами населення (Розенфельд, 2001, с. 187). Звідси випливає легітимність держави.

Особлива роль держави в системі політичних відносин полягає у іiі керівному впливі, адже вона є єдиним інститутом влади, що може впливати на суспільство та здійснювати легітимний примус (Максимець, 2005, с. 105).

Поняття «легітимність» тлумачимо як символ довіри, уявлення, що наявні в суспільній свідомості щодо законності влади та іiі керівників. Основним завданням легітимності є переконання громадян з боку влади щодо свого правочинства. Наприклад, влада наділена правом приймати рішення. Варто зазначити, що легітимність $\epsilon$ важливою ознакою демократичної влади. Отримати підкорення влада може лише у тих випадках, коли сама дотримується та грунтується на цінностях та традиціях (Розенфельд та ін., 2001, с. 195).

Найбільш відома дискусія про законну владу походить від праці М. Вебера (2016, с. 231) «Господарство і суспільство», в якій він визначає «три типи чистого законного панування». Ці типи відрізняються підставами, на яких претензії до легітимності вважаються чинними чи недійсними. Перший чистий тип - легітимна влада (або панування) є раціональним і діє «спираючись на віру в законність прийнятих правил і права тих, хто підкоряється владі за цими правилами, видавати команди (юридичні повноваження)». Другий чистий тип - традиційний діє «спираючись на тверду віру в святість давніх традицій та легітимність тих, хто здійснює владу під ними (традиційний авторитет)». По-третє, правова легітимність, або раціональна, в основі якої лежить добровільність у прийняті законів і яка грунтується на довірі громадян не до конкретної особи-лідера, а до устрою держави загалом. Така легітимність характерна здебільшого для демократичних держав. Кожен з цих типів законності може бути сумісним 3 релігійною основою в певних сенсах. Проте ясно, що традиційний авторитет 
є найбільш придатним для релігійної легітимності, а раціональний авторитет $€$ найбільш демократичним. У випадку традиційного авторитету релігійна традиція може стати основою легітимності: правитель легітимний через традиції, за якими він чи вона функціонує.

Таким чином, поняття «легітимність» визначаємо як важливу ознаку демократичної влади, символ довіри, уявлення, що існують у свідомості громадян та грунтуються на законності влади, визнанні громадянами прав та обов’ язків як їі керівників, так і своїх.

У працях українських дослідників Т. Алексєєва, В. Андрущенка, О. Грищенка, С. Здіорука, М. Міщенка, М. Михальченка, Н. Нижник, В. Цвєткова, Н. Яковенка та інших система держави розглядається, як політичний устрій демократичного типу, що є необхідною умовою, певним способом організації й упорядкування суспільства, збереження його цілісності. Це виділений із суспільства, сформований панівними верствами апарат управління громадськими справами, система офіційних установ та закладів, що перебувають у певному підпорядкуванні, субординації, спеціально призначених для управління суспільними справами. I в такому розумінні держава виступає як апарат управління, сукупність органів державної влади, без яких неможливе функціонування усієї системи державотворення. Водночас, Б. Максимець (2005, с. 146) у своїй науковій роботі підкреслює, що соціально-політичні та інституційні зміни в суспільстві неможливо здійснити без формування й функціонування повноцінних політичних партій, які акумулювали б суспільні інтереси та сприяли їх цілеспрямованому та організованому просуванню в процесі прийняття політичних рішень.

Показовим фактом, що чітко простежується останнім часом в українській політиці $є$ створення партій, діяльність яких спрямована на релігійно-конфесійну ідеологію. Саме така стратегія демонструє політизацію релігії у нашій державі. Відповідно, кожна політична партія або окремі 
політики схильні демонструвати свою належність до конкретної української конфесії або до конкретно визначеного духівництва (Яцишин, 2011, с. 128).

В історії України неодноразово можна зустріти приклади, коли політичні сили в своїй діяльності використовували релігійні засоби впливу на електорат особливо під час кризових періодів державотворення. Водночас, варто зауважити, що політики загальнонаціонального масштабу є досить обережними у власних (офіційних) поглядах щодо свого віросповідання та уподобання між регіональними церквами. Свого роду таке ставлення політиків чи їх політичних партій пояснюється можливою втратою своїх потенційних прихильників серед певної кількості парафіян інших церков. Тому для політичної сили є вкрай важливим орієнтуватися на ту церкву, яка є основною в регіоні, або принаймні переважає серед інших церковних інститутів. Діючи таким чином політична верхівка може отримати в майбутньому максимальну підтримку на виборах (Онищук, 2014).

У сучасних умовах релігія стала більш активною у світському житті, у впливі на політичні погляди парафіян та більш гостро заявляє про свої суспільні інтереси (Свдокимова, 2002). Релігійні організації все більше позиціонуються як дієві інститути впливу в сучасних суспільних процесах, що відіграють значиму роль у зміцнені національної ідентичності українців та власне українського державотворення.

Значущим у національному та світовому масштабі результатом співпраці релігійних організацій та влади $\epsilon$ отримання Томосу про автокефалію української церкви, після підписання якого Україна закріпила свій статус самостійної держави, отримала самостійну Автокефальну Українську Помісну Церкву та водночас проявила свій авторитет в міжнародному політичному просторі. Ця важлива подія демонструє згуртованість українського народу в реалізації своєї національної ідеї. Вона підтверджує ефективність взаємодії релігійних та державних інституцій у розбудові країни, коли важливі політичні рішення сьогодення грунтуються на 
спільній основі, яку можна назвати політизацією церкви, що має відкритий характер, та релігієзацією політики, що має духовний характер.

Висновки і перспективи подальших досліджень. Таким чином, основними напрямами оптимізації впливу релігійних організацій на процеси державотворення в Україні $\epsilon$ : утвердження позицій Автокефальної Української Помісної Церкви серед населення та в міжнародному православному просторі; подолання міжконфесійних конфліктів; подальше позитивне вирішення українського релігійного питання на міжнародному рівні; законодавчого уточнення статусу церкви в суспільно-політичних процесах; формування політично-релігійної складової суспільства як чинника прогресивних змін. Перспективи подальших досліджень убачаємо в аналізі діяльності релігійних інститутів як суб’єктів державної політики в контексті гібридної війни.

\section{ЛІТЕРАТУРА}

1. Вебер, М. 2016. Хозяйство и общество: очерки понимающей соииологии. Москва: Издательный дом Высшей школы экономики.

2. Гараджа, В. и Руткевич, Е. 1996. Религия и общзество: хрестоматия по соичиологии религии: учеб. пособие для вузов. Москва: Институт “Открытое общество”.

3. Свдокимова Т.В. 2002. Взаємовідносини політики $і$ релігії в соиіокультурному просторі (сочіально-філософський аналіз). Кандидат наук. Київський національний університет імені Тараса Шевченка.

4. Коваль I. В. 2007. Взаємодія иеекки та інститутів громадянського суспільства: політологічний аналіз. Кандидат наук. Львівський національний університет імені Івана Франка.

5. Максимець Б. М. 2005. Політичні партії як чинник формування та реалізачіі стратегії державної політики. Кандидат наук. Національна академія державного управління при Президентові України.

6. Онищук В.С. 2014. Участь церков у політичних процесах як чинник державотворення сучасної України. Державне управління: удосконалення та розвиток, [online] 10. Доступно: http://nbuv.gov.ua/UJRN/Duur_2014_10_6. [Дата звернення 3 Жовтень 2019].

7. Парламентська Асамблея Ради Свропи, 1999. Резолюиія 1928. Гарантування прав людини стосовно релігї та переконань і захист релігійних громад від насильства. [online]

Доступно: http://w1.c1.rada.gov.ua/pls/mpz2/docs/1747_rez_1928_(2013).htm\#_ftn1 [Дата звернення 3 Жовтень 2019]. 
8. Розенфельд, Ю., Герасіна, Л., Осипова, Н., Панов, М., Сахань, О. та Ставицька, О. 2001. Політологія: підручник. Харків: Право.

9. Яцишин, У. В., 2011. Роль церкви і духовенства у виборчому процесі України. Українська національна ідея: реалї̈ та перспективи розвитку, 23, с.128-133.

10. Philpott, D., 2007. Explaining the political ambivalence of religion. American Political Science Review, 101, pp. 505-525.

\section{Інформація про автора}

Коновальчук Павло Іванович - аспірант відділу гуманітарної політики Національного інституту стратегічних досліджень; e-mail: pavlo_konovalchuk@ukr.net; ORCID: https://orcid.org/0000-0001-6441-3208.

Стаття надійшла до редакції: 27.11.2019 р. $\quad$ Прийнята до друку: 17.12.2019 p. 